\title{
Duration of an induced resistance of sheep to acute poisoning by Crotalaria retusa seeds
}

\author{
Duração da resistência induzida por Crotalaria retusa em ovinos
}

\author{
Lisanka Angelo Maia ${ }^{\mathrm{I}}$ Clarice Ricardo de Macedo Pessoa ${ }^{\mathrm{I}}$ Angélica Fernandes Rodrigues ${ }^{\mathrm{I}}$ \\ Steven Colegate ${ }^{\mathrm{II}}$ Antônio Flávio Medeiros Dantas ${ }^{\mathrm{I}}$

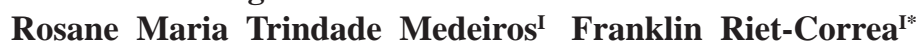

\begin{abstract}
The aim of this study was to determine the duration of the resistance after the end of the ingestion of non-toxic doses of Crotalaria retusa seeds. Ten sheep were divided into 3 groups of 3 animals each and a control group with 1 sheep. To induce resistance, sheep in groups 1, 2 and 3 received 20 daily doses of $2 \mathrm{~g} \mathrm{~kg} \mathrm{~g}^{-1}$ of $\mathrm{C}$. retusa seeds, followed by 7 daily doses of $4 \mathrm{~g} \mathrm{kg^{-1 }}$. To determine the duration of resistance the sheep in groups 1,2 and 3 were challenged orally, 3, 7 and 15 days, respectively, after receiving the last dose of $4 \mathrm{~g} \mathrm{~kg}^{-1}$, with a single dose of $5 \mathrm{~g} \mathrm{~kg}^{-1}$. Sheep of groups 1 and 2 did not develop overt signs of poisoning. Two sheep of group 3, challenged 15 days after the end of the resistance induction period, showed signs of acute poisoning and died. These results suggest that the induced resistance of sheep to acute poisoning by $\boldsymbol{C}$. retusa seeds is of short duration, from 7 to 15 days.
\end{abstract}

Key words: Crotalaria retusa, dehydropyrrolizidine alkaloids, monocrotaline, sheep, resistance to poisoning.

RESUMO

O objetivo deste estudo foi determinar a duração da resistência após a ingestão de doses não tóxicas de sementes de Crotalaria retusa. Dez ovinos foram divididos em três grupos com três animais cada e um grupo controle com um ovino. Para induzir resistência, ovinos dos grupos 1, 2 e 3 receberam 20 doses diárias de $2 \mathrm{~g} \mathrm{~kg}^{-1}$ de sementes de Crotalaria retusa, seguidos de sete doses de $4 \mathrm{~g} \mathrm{~kg}^{-1}$ durante 7 dias. Para determinar a duração da resistência, ovinos dos grupos 1, 2 e 3 foram desafiados oralmente, 3, 7 e 15 dias, respectivamente, após receberem a última dose de $4 \mathrm{~g} \mathrm{~kg}^{-1}$, com uma dose única de $5 \mathrm{~g} \mathrm{~kg}^{-1}$. Ovinos dos grupos 1 e 2 não desenvolveram sinais de intoxicação. Dois ovinos do grupo 3, desafiados 15 dias após o período de indução de resistência, apresentaram sinais de intoxicação aguda e morreram. Estes resultados sugerem que a resistência induzida de ovinos à intoxicação aguda por sementes de C. retusa é de curta duração, de 7 a 15 dias.

Palavras-chave: Crotalaria retusa, alcaloide dehidropirrolizidínicos, monocrotalina, ovinos, resistência à intoxicões.

\section{INTRODUCTION}

In northeastern Brazil, spontaneous ingestion of Crotalaria retusa L. (Figure 1) has been diagnosed as a cause of chronic liver fibrosis and megalocytosis in horses (NOBRE et al., 2004b) and acute liver necrosis in sheep (NOBRE et al., 2005; RIET-CORREA et al., 2011). Recently it was demonstrated experimentally that sheep are susceptible to acute intoxication by monocrotaline (MCT)-containing $\boldsymbol{C}$. retusa seeds and can be poisoned by a single oral dose of seeds equivalent to about 205mg MCT per $\mathrm{kg}$ of body weight $\left(\mathrm{mg} \mathrm{kg}^{-1}\right)$, but they develop a resistance to these acutely lethal oral doses after the daily continuous ingestion of non-toxic dose of seeds equivalent to about $136 \mathrm{mg}$ MCT kg-1 (ANJOS et al., 2010). In a recent outbreak of acute intoxication, 34 out of 150 sheep died in a pasture invaded by $\boldsymbol{C}$. retusa in seed set. During the outbreak, the flock was removed from the paddock but, after four days, 20 ewes from the flock were reintroduced to the paddock. With continual grazing by these sheep and others added to the flock over time, the amount of plant in the paddock decreased

\footnotetext{
'Hospital Veterinário Universidade Federal de Campia Grande, (UFCG), 58700-000, Patos, PB, Brasil. E-mail: franklin.riet@pq.cnpq.br.

*Autor para correspondência.

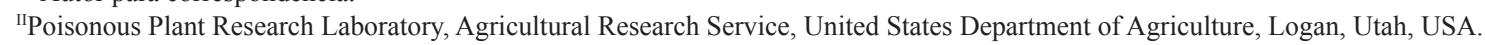




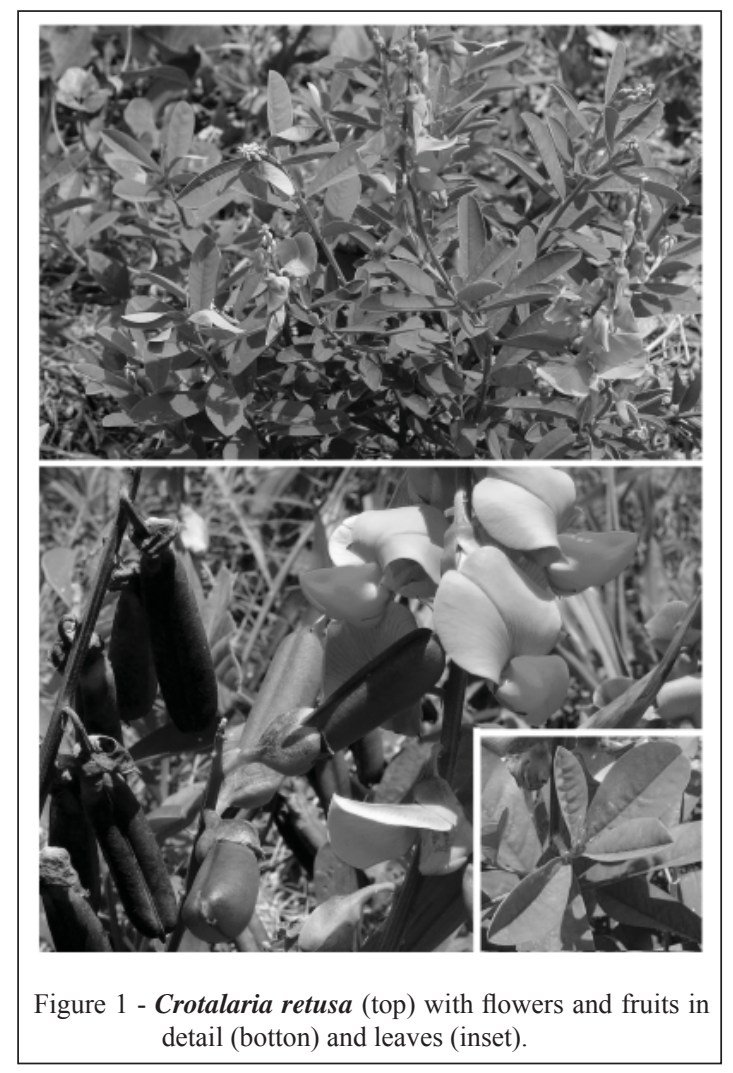

continuously and, after three years, disappeared from the paddock (RIET-CORREA et al., 2011). Based upon those observations it appeared as though sheep could safely be used as biocontrol agents for C. retusa, at least provided the sheep had continual access to the MCT-containing $\boldsymbol{C}$. retusa. The aim of this present study was to determine the duration of the induced resistance if the sheep are denied access to C. retusa for a period before being used as biocontrol agents again.

\section{MATERIALS AND METHODS}

Crotalaria retusa seeds were collected in Serra Negra do Norte, state of Rio Grande do Norte in 2011. MCT concentration of the seeds was determined by HPLC-ESIMS analysis of methanolic extracts using authentic MCT (crotaline; Sigma-Aldrich, USA) as the calibration standard (COLEGATE et al., 2012a, 2012b).

Ten 2-3 years old Santa Inês male sheep were divided into three groups of three animals each and a fourth group with one animal. Prior to the commencement of the study the animals were conditioned for 30 days by feeding corn meal ( $1 \%$ of body weight daily) and with free access to water and freshly cut grass (Echinochloa polystachya). During the study, milled seeds of $\boldsymbol{C}$. retusa were mixed with the corn meal ration while water and grass were continued to be provided ad libitum. Induction of a resistance to acute poisoning by $\boldsymbol{C}$. retusa seed intake was based upon the previous work of ANJOS et al. (2010). Thus, sheep of groups 1, 2 and 3 received daily doses of $2 \mathrm{~g} \mathrm{~kg}^{-1}$ of seeds of $C$. retusa, equivalent to $117.2 \mathrm{mg} \mathrm{MCT} \mathrm{kg}^{-1}$ day $^{-1}$, for 20 days followed by seven daily doses of $4 \mathrm{~g}$ seed $\mathrm{kg}^{-1}$ (234.4mg MCT kg-1). The corn meal mixed with the $C$. retusa seeds was administrated twice a day in amounts equivalent to $0.5 \% \mathrm{bw}$, and the animals were observed until the end of consumption of the entire ration. The sheep from group 4 was left completely untreated except for the same feeding regime and served as a control for serum activities. All animals were weighed weekly for dose correction.

To determine the duration of the induced resistance following cessation of dosing, animals of groups 1, 2 and 3 were challenged, 3, 7 and 15 days respectively after the period of resistance induction, with a single, oral dose of $5 \mathrm{~g}$ seeds $\mathrm{kg}^{-1}$ (293mg MCT $\mathrm{kg}^{-1}$ ) given by gavage. This dose and administration route has previously been shown to cause acute poisoning (NOBRE et al., 2005).

Ciência Rural, v.44, n.6, jun, 2014. 
During the period of resistance induction, blood samples were collected into immediately prior to, and at $24 \mathrm{~h}$ and $72 \mathrm{~h}$ after commencement of the dosing regime and then weekly until the challenge period. Blood samples were also collected at 24, 48 and $72 \mathrm{~h}$ after challenge and, subsequently, every week. Serum activities of gamma-glutamyl transferase (GGT) and aspartate aminotransferase (AST) were determined according to LASSEN (2012).

Sheep were clinically monitored and sheep in extremis were euthanized and immediately necropsied. The experiment was approved by the ethical committee on animal experimentation on the UFCG, process CEP 69-2013. Samples of organs of abdominal and thoracic cavities, and central nervous system were collected, fixed in $10 \%$ formalin, processed routinely by embedding in paraffin and subsequently stained with hematoxylin-eosin (HE) for histological examination.

\section{RESULTS}

Reversed phase HPLC-esi(+)MS analysis of exhaustive methanolic extracts of the milled $\boldsymbol{C}$. retusa seeds revealed $5.86 \pm 0.2 \%(\mathrm{w} / \mathrm{w})$ of MCT quantitated against a 7 point calibration curve of MCT $\left(y=-0.0025 x^{2}+0.3058 x-0.0373 ; \quad R^{2}=0.9985\right)$. Trace levels of MCT- $N$-oxide and two DHPAs with MS data consistent with the MCT-related macrocyclic diesters retusine and crispatine (or similar isobaric isomers) were observed in addition to the major presence of MCT (Figure 2).

Results of the challenge of sheep 1-9 with $5 \mathrm{~g} \mathrm{~kg}^{-1}$ of $\boldsymbol{C}$. retusa seeds 3,7 , and 15 days after the end of the induction period are presented in table 1 . Sheep from groups 1 and 2, challenged 3 and 7 days after the resistance induction period, respectively, did not develop signs of poisoning. Sheep 7 and 8, from group 3, challenged 15 days after the end of the resistance induction period, showed early clinical signs two days after the ingestion of a single dose of $5 \mathrm{~g}$ seed $\mathrm{kg}^{-1}$. Initially, they showed depression and anorexia. Over the following week, mild diarrhea was also observed. On day 10 post-challenge, sheep 7 showed hyperexcitability, ataxia, hypermetria and circling. Twelve days after ingestion both animals were recumbent and were euthanized.

During the period of resistance induction serum activities of AST and GGT of all sheep remained within normal ranges relative to the control sheep 10 in Group 4 (AST 104-136IU L ${ }^{-1}$ and GGT 22$\left.38 \mathrm{IU} \mathrm{L}^{-1}\right)$. Twenty four hours after challenge, serum activities of sheep 1, were elevated (240IU L $\mathrm{L}^{-1}$ for AST, and 68IU L-1 for GGT), but returned to normal on the 3rd day, keeping within normal range until the end of the experiment. In sheep 2 and 3 (Group 1), 4, 5 and 6 (Group 2) and in sheep 10 (control Group 4) serum activities of AST and GGT were within normal

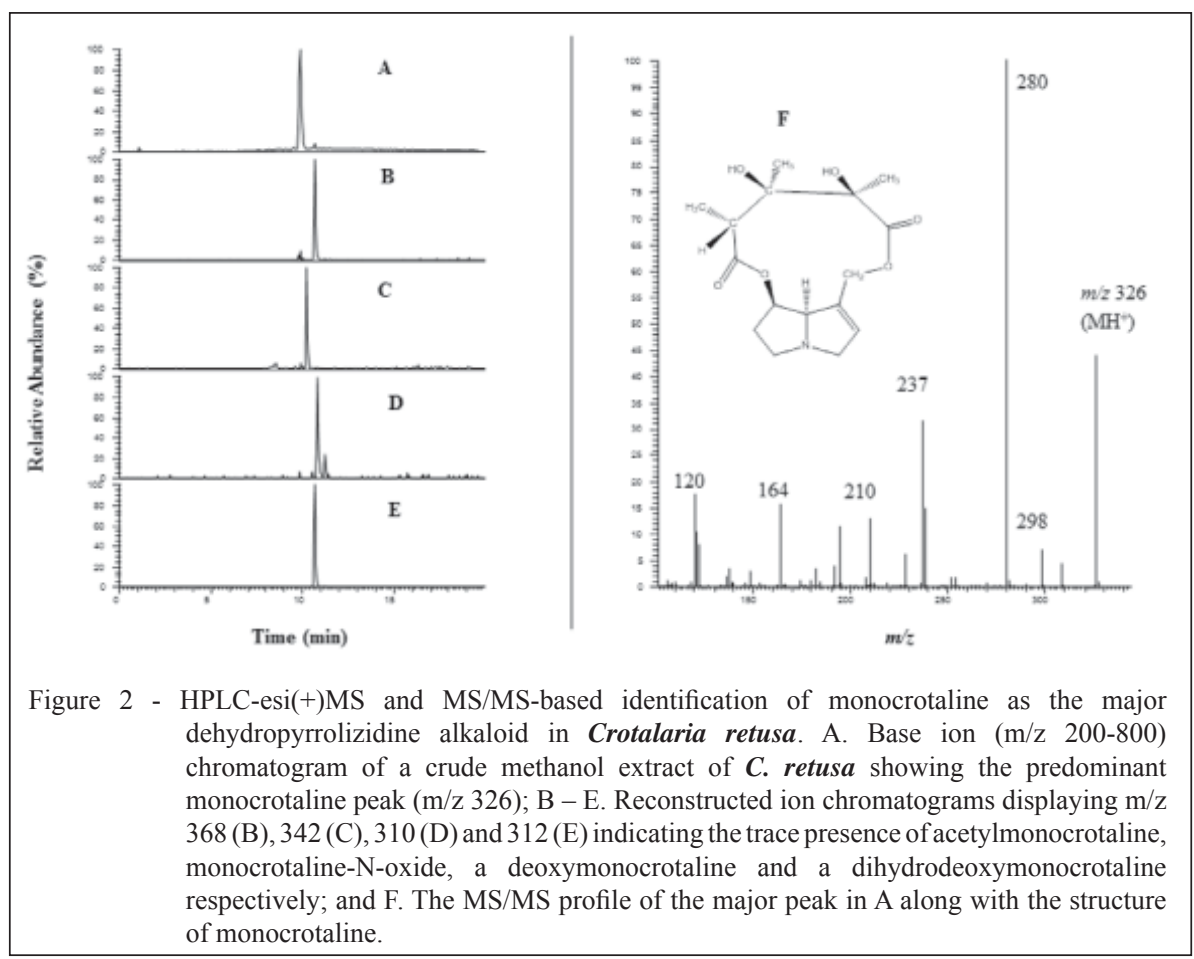

Ciência Rural, v.44, n.6, jun, 2014. 
Table 1 - Results of the challenge of sheep 1-9 with a single gavaged dose of $5 \mathrm{~g} \mathrm{~kg}^{-1}$ bw of C. retusa seeds (293mg MCTkg $\left.{ }^{-1}\right) 3$, 7 ,and 15 days after the end of the induction period in Groups 1, 2, and 3, respectively.

\begin{tabular}{|c|c|c|c|c|}
\hline Group & Sheep $^{\mathrm{a}}$ & Challenge (Days after the end of induction) & Clinical signs & Outcome \\
\hline \multirow[t]{3}{*}{ Group 1} & 1 & 3 & Absent & Survive \\
\hline & 2 & 3 & Absent & Survive \\
\hline & 3 & 3 & Absent & Survive \\
\hline \multirow[t]{3}{*}{ Group 2} & 3 & 7 & Absent & Survive \\
\hline & 5 & 7 & Absent & Survive \\
\hline & 6 & 7 & Absent & Survive \\
\hline \multirow[t]{3}{*}{ Group 3} & 7 & 15 & Present & Died \\
\hline & 8 & 15 & Present & Died \\
\hline & 9 & 15 & Absent & Survive \\
\hline Group 4 & 10 & \multicolumn{3}{|c|}{ Untreated control sheep for serum activities } \\
\hline
\end{tabular}

${ }^{\text {a }}$ Before challenge, sheep 1-9 received 20 daily doses of $2 \mathrm{~g} \mathrm{~kg}^{-1}$ bw of $\boldsymbol{C}$. retusa seeds (117.2 $\mathrm{mg} \mathrm{MCT} \mathrm{kg}^{-1}$ day $^{-1}$ ) followed by 7 daily doses of $4 \mathrm{~g}$ seeds $/ \mathrm{kg}\left(234.4 \mathrm{mg} \mathrm{MCT} \mathrm{kg}^{-1}\right.$ day $\left.^{-1}\right)$.

ranges. In sheep 7 and 8 (Group 3), serum activities of GGT and AST increased 24 hours after challenge and remained high until death (204-639IU L ${ }^{-1}$ for AST and 45-206IU L ${ }^{-1}$ for GGT). Sheep 9 (Group 3) did not show clinical signs. However, at 48 and 72 hours after challenge the serum activities of AST (225 and 303IU L $\mathrm{I}^{-1}$ ) and GGT (68 and 76IU L-1) were elevated but returned to normal by the $9^{\text {th }}$ day post-challenge.

At necropsy of sheep 7 and 8, the liver showed an increased lobular pattern with reddish areas interspersed with pale areas, best evidenced on the cut surface. The gallbladder was distended and edematous with a thickened wall. The heart had multifocal areas of hemorrhage in the subepicardial and subendocardial surfaces. The main histological lesion was centrilobular liver necrosis (Figure 3). Hepatocytes with intracytoplasmic vacuoles of various sizes were observed mainly around the necrotic areas. Vacuoles, characteristic of hepatic encephalopathy were observed in the white matter of the central nervous system, mainly in the rostral colliculus, thalamus, cerebellar peduncle, frontal cortex, parietal cortex, and cerebellum.

\section{DISCUSSION}

These results confirm that repeated nontoxic doses of monocrotaline induce resistance to the poisoning of sheep exposed to seeds of $\boldsymbol{C}$. retusa as demonstrated by ANJOS et al. (2010). However, the present study indicates that this resistance is of short duration, between 7 and 15 days after cessation of the non-acutely toxic exposures. Similar results were observed with leaves and stems of Senecio brasiliensis in sheep that received daily non-toxic doses of $15 \mathrm{~g}$ plant material $\mathrm{kg}^{-1}$ for 30 days and $30 \mathrm{~g}$ plant material $\mathrm{kg}^{-1}$ for another 10 days. The sheep challenged at the end of the administration period were resistant to an acute toxic dose but those challenged 15 and 45 days post the resistance induction regime succumbed to an acutely toxic dose (GRECCO et al., 2012).

The adaptive responses to xenobiotics are often mediated by binding receptors. A variety of xenobiotic receptors are expressed in the liver. After ligand binding, the receptor complex is translocated to the nucleus where it activates gene expression through interaction with DNA xenobiotic response elements. The response of this interaction includes the induction of enzymes of phase I and II which could result in detoxification or activation, the latter forming a toxic substance (WILLIAMS \& IATROPOULOS, 2002). There are several pathways of pyrrolizidine alkaloid metabolism including: 1) hydrolysis by tissue esterases to form non-toxic necine bases, which are eliminated in the urine; 2) $\mathrm{N}$-oxidation to form more readily eliminated $\mathrm{N}$-oxides; 3) dehydrogenation, which leads to formation of didehydropyrrolizidines (the "pyrrolic" forms) responsible for acute toxicity; 4) didehydropyrrolizidine alkaloid conjugates with glutathione forming water soluble compounds, which are eliminated by the bile and urine (EDGAR et al., 2011). It has been reported that exposure to DHPAs induces changes in the rumen microflora that lead to detoxification of the DHPAs (LANIGAN, 1976). Alternatively, xenobiotic agents can be inducers of detoxification processes in the liver and this adaptive effect can be reversible upon cessation of exposure (WILLIAMS \& IATROPOULOS, 2002), thereby potentially explaining the rapid loss of resistance following cessation of non-acutely toxic exposure. 


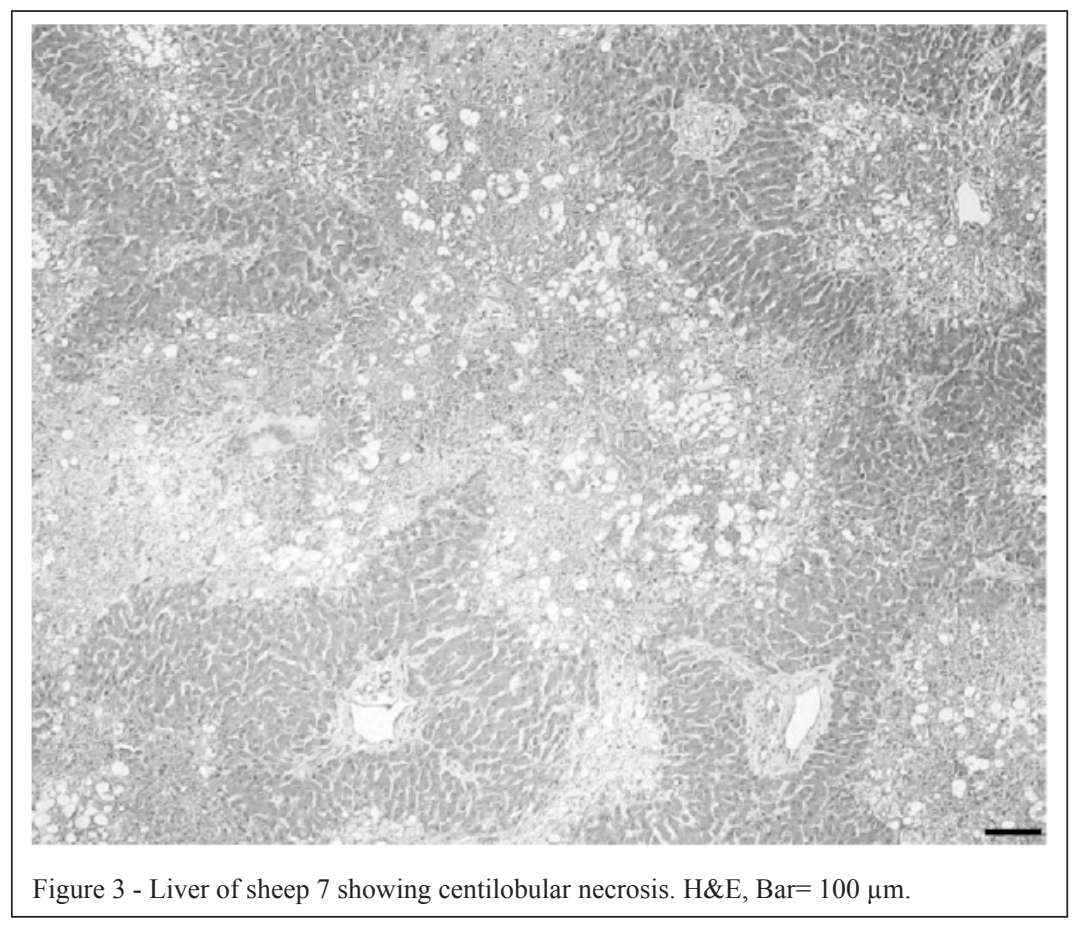

Considering the results of this and previous work (ANJOS et al., 2010; RIET-CORREA et al., 2011) resistant sheep can be used for the biologic control of $\boldsymbol{C}$. retusa provided that the rapid loss of resistance is taken into account. Because leaves of $\boldsymbol{C}$. retusa contain concentrations of MCT, from $0.16 \%$ to $0.5 \%$ (NOBRE et al., 2004 a,b, 2005) they are much less toxic than the seeds. In a previous experiment, one sheep ingested large amounts of aerial parts of the plant (285.6kg in 270 days) without showing clinical signs (NOBRE et al., 2005). Therefore it is suggested that the safest approach to using sheep to control infestations of $\boldsymbol{C}$. retusa is to introduce the sheep to the paddock when the plant is young and maintain their continued presence. The lower level exposure to the DHPAs would be expected to induce the resistance needed to allow the sheep to safely ingest the seeded $\boldsymbol{C}$. retusa. Alternatively, if the plants are already in seed, then sheep could be allowed access for gradually increasing periods of time however, in view of the rapid loss of resistance to poisoning, it is not recommended to remove grazing sheep for periods longer than 7 days from the paddocks with C. retusa.

\section{CONCLUSION}

The continuous daily ingestion of nontoxic doses of $\boldsymbol{C}$. retusa seeds induces resistance in sheep, however this resistance is of short duration, from 7 to 15 days after the end of consumption. Although the mechanism of this induced resistance is unknown this knowledge will nevertheless help in the rational and safer use of sheep in the control of C. retusa.

\section{ETHICS COMMITTEE}

The experiment was approved be the ethical 69-2013.

\section{ACKNOWLEDGMENTS}

This work was supported by National Institute for Science and Technology for the Control of Plant Poisonings, Conselho Nacional de Desenvolvimento Científico e Tecnológico (CNPq), grant 573534/2008-0.

\section{REFERENCES}

ANJOS, B.L. et al. Poisoning of sheep by seeds of Crotalaria retusa: Acquired resistance by continuous administration of low doses. Toxicon, v.55, p.28-32, 2010. Available from: <http: // dx.doi.org/10.1016/j.toxicon.2009.06.028>. Accessed: Mar. 16, 2011. doi: 10.1016/j.toxicon.2009.06.028.

COLEGATE, S.M. et al. Dehydropyrrolizidine alkaloids in two Cryptantha species: including two new open chain diesters one of which is amphoteric. 2012a. Phytochemical Analysis. Available from:<http://onlinelibrary.wiley.com/doi/10.1002/pca.2400/ abstract $>$. Accessed: Nov. 12, 2012. doi: 10.1002/pca.2400.

COLEGATE, S.M. et al. Dehydropyrrolizidine alkaloids, including monoesters with an unusual esterifying acid, from 
cultivated Crotalaria juncea (Sunn Hemp cv.'Tropic Sun'). Journal of Agricultural and Food Chemistry, v.60, p.35413550, 2012b. Available from: <http://www.ncbi.nlm.nih.gov/pmc/ articles/PMC3366594>. Accessed: Nov. 12, 2012. doi: 10.1021/ jf205296s.

EDGAR, J.A. et al. Pyrrolizidine alkaloids in food: a spectrum of potential health consequences. Food Additives and Contaminants, v.28, p.308-324, 2011. Available from: <http://www.tandfonline. com/doi/pdf/10.1080/19440049.2010.547520> Accessed: Out. 24, 2012. doi: $10.1080 / 19440049.2010 .547520$.

GRECCO, F.B. et al. Intoxicação experimental aguda por Senecio brasiliensis em ovinos e indução de resistência a intoxicação. Pesquisa Veterinária Brasileira, v.32, p.912916, 2012. Available from: <http://dx.doi.org/10.1590/S0100736X2012000900015>. Accessed: Mar. 12, 2011. doi: 10.1590/ S0100-736X2012000900015.

LANIGAN, G.W. Peptococcus heliotrinreciucans, sp.nov., a cytochrome-producing anaerobe which metabolizes pyrrolizidine alkaloids. Journal of General Microbiology, v.94, p.1-10, 1976. Available from: $<$ http://mic.sgmjournals.org/content/94/1/1. short>. Accessed: Ago. 18, 2012. doi: 10.1099/00221287-94-1-1.

LASSEN, E.D. Laboratory evaluation of the liver. In: THRALL, M.A. Veterinary hematology and clinical chemistry. Philadelphia: Lippincott Williams \& Wilkins, 2004. Cap.23, p.355-377.
NOBRE, V.M.T. et al. Intoxication by Crotalaria retusa in ruminants and Equidae in the state of Paraíba, northeastern Brazil. In: ACAMOVICH, T. et al. (Eds.). Plant poisoning and related toxins. Glasgow: CAB International, 2004a. p.275-279.

NOBRE, V.M.T. et al. Intoxicacão por Crotalaria retusa (Fabaceae) em equídeos no semi-arido da Paraiba. Pesquisa Veterinária Brasileira, v.24, p.132-143, 2004b. Available from: <http://dx.doi. org/10.1590/S0100-736X2004000300004>. Accessed: Nov. 20, 2011. doi: 10.1590/S0100-736X2004000300004.

NOBRE, V.M.T. et al. Acute intoxication by Crotalaria retusa in sheep. Toxicon, v.45, p.347-352, 2005. Available from: $<\mathrm{http}: / /$ dx.doi.org/10.1016/j.toxicon.2004.11.005.> Accessed: Fev. 23, 2011. doi: 10.1016/j.toxicon.2004.11.005.

RIET-CORREA, F. et al. Spontaneous acute poisoning by Crotalaria retusa in sheep and biological control of this plant with sheep. Toxicon, v.58, p.606-609, 2011. Available from: $<$ http:// dx.doi.org/10.1016/j.toxicon.2011.09.002>. Accessed: Jul. 12, 2012. doi:10.1016/j.toxicon.2011.09.002

WILLIAMS, G.M.; IATROPOULOS, M.J. Alteration of liver cell function and proliferation: differentiation between adaptation and toxicity. Toxicologic Pathology, v.30, p.41-53, 2002. Available from: $<$ http://tpx.sagepub.com/content/30/1/41.full.pdf $>$. Accessed: Jan. 20, 2012. doi: 10.1080/01926230252824699. 